\title{
Perbandingan Metode Pemekatan Kuderna Danish dan Rotary Evaporator dalam Penentuan Total Petroleum Hydrocarbon(TPH) Secara Kromatografi Gas
}

\author{
Adrian Gunawan $^{1^{*}}$, Ashadi Sasongko ${ }^{1}$, Rusy Dina Sabila ${ }^{2}$ \\ ${ }^{1}$ Institut Teknologi Kalimantan, Kampus ITK Karang Joang, Balikpapan, 76127, Indonesia \\ ${ }^{2}$ Program Diploma Analisis Kimia, Institut Pertanian Bogor, Jl. Kumbang 14 Bogor, 16151, Indonesia \\ "a.gunawan@itk.ac.id
}

\begin{abstract}
Total Petroleum Hydrocarbon (TPH) is a term used to describe a large family of chemical compounds derived from crude oil. Concentration method that is used for the analysis of TPH is Kuderna Danish evaporator, which is then modified so that concentration can also be done with a rotary evaporator. Methods experiments on gas chromatographic determination dokosana consists of the preparation, testing, and data processing. Parameters tested include verification of linearity, precision, and accuracy. Real difference test at concentrations of 100 and 500 $\mathrm{mg} / \mathrm{L}$ resulted in calculated $F$ value of 3.6493 and 1.8586 with a value $T$ calculated at 4.4734 and 1.9376 . Value $T$ count at a concentration of $100 \mathrm{mg} / \mathrm{L}$ is greater than T table is 2:18 so that at these concentrations both methods show significant differences, but the $F$ count and $T$ count obtained at a concentration of $500 \mathrm{mg} / \mathrm{L}$ is smaller than $F$ table and $T$ table, ie 5,820 and 2:18 indicate that both methods were not significantly different at the 95\% confidence interval.
\end{abstract}

Keywords : dokosana, gas chromatography, kuderna danish evaporator, rotary evaporator, total petroleum hydrocarbons

\begin{abstract}
Abstrak
Total Petroleum Hydrocarbon (TPH) adalah istilah yang digunakan untuk menggambarkan keluarga besar senyawa kimia yang berasal dari minyak mentah. Metode pemekatan awal yang digunakan untuk analisis TPH adalah Kuderna Danish evaporator, yang kemudian mengalami modifikasi sehingga pemekatan dapat pula dilakukan dengan rotary evaporator. Metode percobaan pada penetapan TPH secara kromatografi gas terdiri dari preparasi, pengujian, dan pengolahan data. Parameter verifikasi yang diuji antara lain linearitas, presisi, dan akurasi. Uji beda nyata pada konsentrasi 100 dan $500 \mathrm{mg} / \mathrm{L}$ menghasilkan nilai $\mathrm{F}$ hitung sebesar 3.6493 dan 1.8586 dengan nilai $\mathrm{T}$ hitung sebesar 4.4734 dan 1.9376 . Nilai T hitung pada konsentrasi $100 \mathrm{mg} / \mathrm{L}$ lebih besar dari $\mathrm{T}$ tabel yaitu 2.18 sehingga pada konsentrasi tersebut kedua metode menunjukkan perbedaan nyata, namun nilai $\mathrm{F}$ hitung dan $\mathrm{T}$ hitung yang diperoleh pada konsentrasi $500 \mathrm{mg} / \mathrm{L}$ lebih kecil dari nilai $\mathrm{F}$ tabel dan $\mathrm{T}$ tabel, yaitu 5.820 dan 2.18 yang menunjukkan bahwa kedua metode tidak berbeda nyata pada selang kepercayaan $95 \%$.
\end{abstract}

Kata kunci : dokosana, kromatografi gas, kuderna danish evaporator, rotary evaporator, total petroleum hydrocarbon

\section{Pendahuluan}

Petroleum (minyak bumi) merupakan sumber energi utama yang digunakan pada industri transportasi dan rumah tangga. Kegiatan industri minyak bumi merupakan suatu rangkaian proses yang kompleks mulai dari hulu sampai hilir. Pesatnya perkembangan di sektor industri minyak selain memberikan dampak positif yaitu meningkatkan kesejahteraan rakyat juga memberikan efek samping dengan terjadinya pencemaran lingkungan [1]. Pencemaran lingkungan dapat terjadi pada tanah, udara, dan air. Pencemaran di tanah dapat melalui peresapan ke dalam lapisan tanah dan tertahan dalam jangka waktu yang cukup lama. Uap dari senyawa ini juga 
dapat mencemari udara dan berbahaya bagi kesehatan manusia bila terhirup, sedangkan pencemaran pada air dapat terjadi melalui kebocoran secara langsung. Air merupakan substansi yang paling mudah tercemar karena merupakan pelarut universal.

Pencemaran air adalah masalah yang penting dalam aspek lingkungan. Pencemaran air merupakan masuknya makhluk hidup, zat energi, dan komponen lain ke dalam air oleh kegiatan manusia, sehingga kualitas air menurun sampai ke tingkat tertentu. Salah satu jenis dari Total Petroleum Hydrocarbon (TPH) yang dapat mencemari air adalah petroleum hydrocarbon atom $\mathrm{C}_{22}$. Senyawa ini dipilih dalam pengujian karena memiliki sifatsifat yang mewakili senyawa-senyawa petroleum lainnya. Petroleum hydrocarbon atom $\mathrm{C}_{22}$ (dokosana) merupakan produk dari pemurnian minyak mentah yang terpisah pada fraksi minyak gas berat. Senyawa tersebut dapat tersapu air hujan atau masuk ke dalam tanah kemudian terjerap dan terakumulasi sebagai zat beracun [2]. Apabila terkonsumsi dalam jumlah besar, senyawa ini dapat mengganggu sistem pernafasan dan juga mengiritasi mata dan kulit. Oleh karena itu, senyawa tersebut harus diuji dengan metode yang terpercaya.

Polusi TPH terhadap lahan pertanian penting untuk diteliti. Di Guangzhou, China,tujuh puluh sampel tanah dikumpulkan dari lapisan permukaan $(0-20 \mathrm{~cm})$ di sekitar kompleks petrokimia untuk dianalisis [3]. TPH banyak digunakan sebagai salah satu penanda suatu lokasi telah terkontaminasi. Analisis terhadap TPH dan tipe tanah sangat penting untuk dilakukan [4]. Sebagian besar TPH terdiri atas fraksi berat minyak bumi. Ketika endapan TPH terlepas ke lingkungan maka akan menyebabkan kerusakan serius di lingkungan perairan dan akan bertahan dengan efek toksik dalam waktu yang cukup lama. Namun jika ditangani dengan baik dan optimal, maka hidrokarbon akan terdegradasi secara alami dan polusi dapat dihilangkan [5].

Metode gravimetrik yang menggunakan nheksana sebagai pelarut ekstraksi untuk penentuan minyak dan lemak, dan juga bahan nonpolar, telah menjadi pilihan utama, walaupun kurang sesuai karena adanya pemekatan senyawa volatil. Metode yang sering digunakan lainnya Termasuk kromatografi gas dengan detektor ionisasi nyala (FID) atau detektor spektrometrik massa (MSD) [6]. Metode GC-FID memiliki gangguan analisis yang sedikit dan biaya analitisnya lebih rendah daripada metode IR, walaupun GC-FID lebih memakan waktu [7].

Analisis TPH menggunakan metode kromatografi gas dengan Flame Ionization Detector (FID) yang mengacu pada metode uji standar United State Enviromental Protection Agency (USEPA) nomor 3520C. Metode ini pada awalnya menggunakan pemekatan dengan Kuderna Danish evaporator. Sejalan dengan perkembangannya, metode ini mengalami modifikasi. Pemekatan contoh kemudian diganti dengan menggunakan rotary evaporator. Modifikasi ini dilakukan berdasarkan pertimbangan efisiensi waktu.

Suatu metode yang telah mengalami modifikasi memerlukan suatu verifikasi untuk membuktikan bahwa metode yang digunakan tersebut menghasilkan data yang dapat dipercaya. Selain itu, perlu juga dilakukan perbandingan antara kedua metode untuk mengetahui keberterimaan hasil yang diperoleh dari kedua metode tersebut. Parameter-parameter yang diujikan terhadap kedua metode adalah linearitas, presisi, dan akurasi. Uji beda nyata juga dilakukan pada data yang diperoleh dari kedua metode. Hasil uji beda nyata tersebut dibandingkan secara statistika dengan uji $\mathrm{F}$ yang dilanjutkan dengan uji $\mathrm{T}$ untuk mengetahui ada atau tidaknya perbedaan yang nyata dan signifikan serta kemampuan kedua metode tersebut untuk saling menggantikan sebagai analisis rutin.

\section{Metoda Penelitian}

\subsection{Alat dan Bahan}

Alat-alat yang digunakan ialah syringe $2.5 \mathrm{~mL}$, labu takar 10, 50, dan $100 \mathrm{~mL}$, rotary evaporator, Kuderna Danish evaporator, kromatografi gas Agilent Technologies 
7890A, gelas piala $50 \mathrm{~mL}$, neraca analitik, batang pengaduk, botol akuades, water bath, vial, statif, klem, pipet mikro, blue tip, insert glass, dan sudip.Bahan-bahan yang digunakan ialah aseton, diklorometana, standar dokosana $\left(\mathrm{C}_{22}\right) 100 \%$ dan akuades.

\subsection{Metode Percobaan}

Metode percobaan yang dilakukan ialah uji linearitas, uji presisi, uji akurasi, dan uji beda nyata. Kadar TPH (dokosana) ditentukan dengan pemisahan menggunakan kolom HP5 (Agilent $19091 \mathrm{~J}, 41330 \mathrm{~m}$ x $320 \mu \mathrm{m} \times 0.25$ $\mu \mathrm{m})$ dengan fase diam $5 \%$ fenil metil siloksan, fase gerak (gas pembawa) nitrogen dengan aliran gas $23 \mathrm{~mL} / \mathrm{menit}$, gas pembakar hidrogen dan udara dengan aliran gas 40 dan $400 \mathrm{~mL} / \mathrm{menit}$, suhu injektor $300{ }^{\circ} \mathrm{C}$ dengan volume injeksi $3 \mu \mathrm{L}$ dan mode injeksi splitless, detektor FID dengan suhu $300{ }^{\circ} \mathrm{C}$, dan suhu kolom dengan mode terprogram (suhu awal $50{ }^{\circ} \mathrm{C}$, ditahan selama 3 menit kemudian dinaikkan $25{ }^{\circ} \mathrm{C}$ selama 10 menit sampai $300{ }^{\circ} \mathrm{C}$ dan ditahan 12 menit).

\subsubsection{Pembuatan Kurva Kalibrasi Standar Dokosana}

Pembuatan standar dilakukan dengan cara standar dokosana $100 \%$ ditimbang sebanyak $0.1 \mathrm{~g}$, lalu dilarutkan dan ditera dengan diklorometana dalam labu takar $100 \mathrm{~mL}$. Kemudian dibuat deret standar 10, 25, 50, 100, 250, 500, dan $1000 \mathrm{mg} / \mathrm{L}$ dengan cara standar tersebut dipipet sebanyak $0.1,0.25,0.5,1,2.5$, 5 dan $10 \mathrm{~mL}$ ke dalam labu takar $10 \mathrm{~mL}$. Larutan kemudian ditera dengan diklorometana. Setelah itu, larutan standar siap diinjeksikan ke dalam kromatografi gas.

\subsubsection{Pembuatan Larutan Induk Dokosana}

Larutan induk dokosana $1000 \mathrm{mg} / \mathrm{L}$ dibuat dengan cara sebanyak $0.1 \mathrm{~g}$ standar dokosana $100 \%$ ditimbang dan dilarutkan dengan diklorometana. Larutan ditera dengan diklorometana ke dalam labu takar $100 \mathrm{~mL}$ kemudian dihomogenkan.

\subsubsection{Preparasi Sampel dengan Metode Kuderna Danish evaporator}

Sebanyak $0.3 \mathrm{~mL}$ (konsentrasi $100 \mathrm{mg} / \mathrm{L}$ ) dan $1.5 \mathrm{~mL}$ (konsentrasi $500 \mathrm{mg} / \mathrm{L}$ ) larutan induk dokosana $1000 \mathrm{mg} / \mathrm{L}$ dipipet dan ditera dengan diklorometana ke dalam labu takar 50 $\mathrm{mL}$. Selanjutnya, larutan dipindahkan ke dalam Kuderna Danishevaporator dan diuapkan pada suhu $60{ }^{\circ} \mathrm{C}$ sampai volume larutan $3 \mathrm{~mL}$. Larutan dipindahkan ke dalam vial $3 \mathrm{~mL}$, lalu dianalisis dengan kromatografi gas.

\subsubsection{Preparasi Sampel dengan Metode Rotary Evaporator}

Sebanyak $0.3 \mathrm{~mL}$ (konsentrasi $100 \mathrm{mg} / \mathrm{L}$ ) dan $1.5 \mathrm{~mL}$ (konsentrasi $500 \mathrm{mg} / \mathrm{L}$ ) larutan induk dokosana $1000 \mathrm{mg} / \mathrm{L}$ dipipet dan ditera dengan diklorometana ke dalam labu takar 50 $\mathrm{mL}$. Selanjutnya, larutan dipindahkan ke dalam labu didih $250 \mathrm{~mL}$ dan dipekatkan dengan penguapan putar pada suhu $60{ }^{\circ} \mathrm{C}$ sampai ekstrak sekitar $3 \mathrm{~mL}$. Ekstrak dimasukkan ke dalam vial $3 \mathrm{~mL}$, lalu dianalisis dengan kromatografi gas.

\subsection{Uji Statistik}

Uji statistik yang dilakukan meliputi uji linearitas, presisi, akurasi, dan uji beda nyata. Uji linearitas dilakukan dengan cara standar dokosana $100 \%$ ditimbang sebanyak $0.1 \mathrm{~g}$, lalu dilarutkan dan ditera dengan diklorometana dalam labu takar $100 \mathrm{~mL}$. Kemudian dibuat deret standar 10, 25, 50, 100, 250, 500, dan $1000 \mathrm{mg} / \mathrm{L}$ dengan cara standar tersebut dipipet sebanyak $0.1,0.25,0.5,1,2.5,5$ dan $10 \mathrm{~mL}$ ke dalam labu takar $10 \mathrm{~mL}$. Larutan kemudian ditera dengan diklorometana. Setelah itu, larutan standar siap diinjeksikan ke dalam kromatografi gas. Kemudian data yang dihasilkan diolah.

Uji presisi atau keterulangan dilakukan dengan cara kadar TPH dalam sampel ditentukan sebanyak 7 kali ulangan. Pengujian dilakukan terhadap dua titik konsentrasi, yaitu sedang (100 mg/L) dan tinggi (500 mg/L). Metode yang digunakan sama seperti preparasi sampel. Setelah sampel diukur, lalu ditentukan 
nilai persen simpangan baku relatif (\% RSD) yang diperoleh. Nilai \% RSD kemudian dibandingkan dengan nilai $2 / 3 \mathrm{CV}_{\text {Horwitz }}$.

Uji akurasi atau kecermatan dilakukan dengan cara kadar TPH dalam sampel ditentukan sebanyak 7 kali ulangan. Pengujian dilakukan terhadap dua titik konsentrasi, yaitu sedang (100 mg/L) dan tinggi $(500 \mathrm{mg} / \mathrm{L})$. Metode yang digunakan sama seperti preparasi sampel. Setelah sampel diukur, lalu ditentukan nilai persen perolehan kembali (\% recovery) sampel.

Sampel yang telah didestilasi dengan masing-masing metode ditambahkan dengan diklorometana sebanyak $3 \mathrm{~mL}$ kemudian di masukkan ke dalam vial yang berisi insert glass. Kurva standar yang digunakan adalah kurva yang dibuat pada saat pengujian linearitas. Masing-masing vial kemudian dimasukkan ke dalam alat kromatografi gas dan data yang dihasilkan diolah untuk uji beda nyata.

\section{Hasil Penelitian}

Analisis TPH mengukur hidrokarbon dengan panjang rantai $\mathrm{C}_{6}$ hingga $\mathrm{C}_{36}$ secara kromatografi gas. Senyawa yang diukur pada percobaan adalah dokosana dengan jumlah atom $\mathrm{C}_{22}$. Gas yang digunakan pada pengujian TPH adalah hidrogen, udara dan nitrogen. Hidrogen dan udara berfungsi sebagai gas pembakar, karena sifatnya yang mudah terbakar, sedangkan nitrogen berperan sebagai gas pembawa yang akan membawa uap sampel masuk ke dalam kolom untuk memisahkan komponen-komponen dalam campuran dan selanjutnya akan masuk ke detektor untuk dideteksi secara individual. Gas tersebut digunakan sebagai gas pembawa karena bersifat inert (tidak bereaksi) dengan analit maupun fase diam, dapat diperoleh dengan kemurnian tinggi sehingga noise yang terjadi tidak terlalu besar dan tidak terjadi pelebaran puncak (peak). Selain itu, gas nitrogen cukup peka bila dideteksi dengan detektor ionisasi nyala.

Injeksi sampel pada pengukuran petroleum hydrocarbon atom $\mathrm{C}_{22}$ dilakukan secara otomatis dengan autosampler. Hal tersebut dilakukan untuk mendapatkan injeksi yang cepat, tepat, benar, dan akurat. Karena saat sampel dimasukkan ke dalam injektor, seketika itu pula sampel tersebut diubah menjadi bentuk gas. Jika sistem injeksinya lambat, maka senyawa yang berada dalam waktu retensi tertentu tidakterdeteksi oleh detektor. Tipe injeksi yang digunakan ialah splitless injection, karena pengukuran dokosana merupakan analisis trace atau sedikit, maka sampel yang disuntikkan seluruhnya dimasukkan ke dalam kolom dan sedikit yang dibuang [8].

Suhu yang digunakan pada pengukuran menggunakan mode terprogram, yaitu suhu kolom divariasikan selama pengukuran berlangsung. Pengukuran dengan mode operasi ini meningkatkan analit yang memiliki titik didih yang berdekatan untuk saling memisah dengan baik, sehingga diperoleh peak yang tidak saling bertumpukan. Detektor yang digunakan adalah Flame Ionization Detector (FID). Detektor ini digunakan karena memiliki sensitivitas yang baik untuk hampir semua senyawa organik. FID hanya berespon terhadap jumlah atom karbon yang masuk ke dalam detektor per unit waktu, maka detektor ini lebih sensitif terhadap massa dibandingkan konsentrasi. Kisaran massa yang dapat dideteksi oleh detektor FID cukup luas, yaitu $10^{-11}$ sampai $10^{-4} \mathrm{~g}[9]$.

Pengukuran menggunakan kromatografi gas menghasilkan sinyal berupa puncak (peak) yang menunjukkan hubungan antara waktu retensi dan luas area yang menunjukkan konsentrasi. Konsentrasi dokosana yang diperoleh dari pengukuran diujikan terhadap beberapa parameter, yaitu linearitas, presisi, akurasi, dan uji beda nyata yang diuji secara statistika. Hasil uji tersebut kemudian dibandingkan dengan kriteria keberterimaan.

\subsection{Hasil Uji Linearitas}

Uji linearitas suatu metode analisis dilakukan untuk membuktikan adanyahubungan yang proporsional antara konsentrasi analit (x) dengan respon alat 
(y).Parameter yang digunakan pada uji linearitas untuk menunjukkan adanya hubungan yang linear antara konsentrasi analit dengan luas area dinyatakan dalam koefisien korelasi (r). Pengujian linearitas dilakukan dengan pembacaan deret standar petroleum hydrocarbon atom $\mathrm{C}_{22}$ (dokosana) pada rentang konsentrasi 10-1000 $\mathrm{mg} / \mathrm{L}$. Selanjutnya ditentukan nilai kemiringan (b), intersep (a), dan koefisien korelasi (r). Hasil uji lineritas metode analisis penetapan kadar TPH (dokosana) disajikan pada Gambar 1 dan Tabel 1.

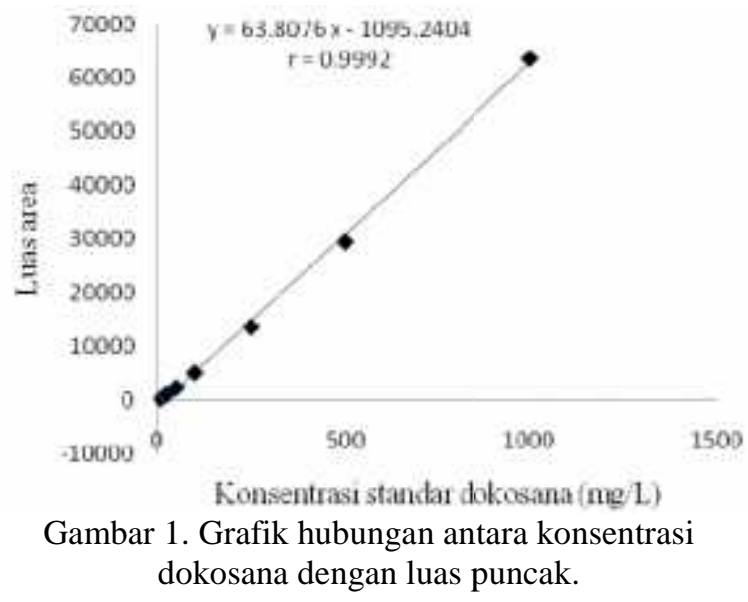

Berdasarkan uji linearitas metode analisis penetapan TPH (dokosana) menunjukan bahwa adanya hubungan yang berbanding lurus antara konsentrasi dengan luas puncak. Semakin besar konsentrasi suatu standar, maka semakin besar pula luas puncak yang dihasilkan. Persamaan linear yang diperoleh dari percobaan yaitu $\mathrm{y}=63.8076 x-1095.2404$ dengan koefisien korelasi sebesar 0.9992. Menurut Association of Official Analytical Chemist (AOAC) bahwa suatu metode akan dikatakan linear apabila menghasilkan nilai koefisien korelasi $\geq 0.9900$ [10]. Hal ini menunjukan bahwa metode penetapan kadar TPH (dokosana) memberikan hasil yang linear karena memenuhi syarat keberterimaan koefisien korelasi (r) pada rentang 10-1000 $\mathrm{mg} / \mathrm{L}$.

Tabel 1 Hasil uji linearitas

\begin{tabular}{cc}
\hline Parameter & Nilai \\
\hline Linearitas (rentang $(\mathrm{mg} / \mathrm{L}))$ & $10-1000$
\end{tabular}
Regresi $\left(\mathrm{r}^{2}\right)$
Koefisien korelasi (r)
Kemiringan (b)
Intersep (a)
0.9984
0.9992
63.8076
$-1095.2404$

. Contoh kromatogram uji linearitas pada konsentrasi $10 \mathrm{mg} / \mathrm{L}$ dapat dilihat pada Gambar 2. Gambar 2 menunjukkan peak (puncak) standar dokosana pada konsentrasi $10 \mathrm{mg} / \mathrm{L}$ dengan waktu retensi selama 11.591 menit dengan luas area sebesar 349.49216.

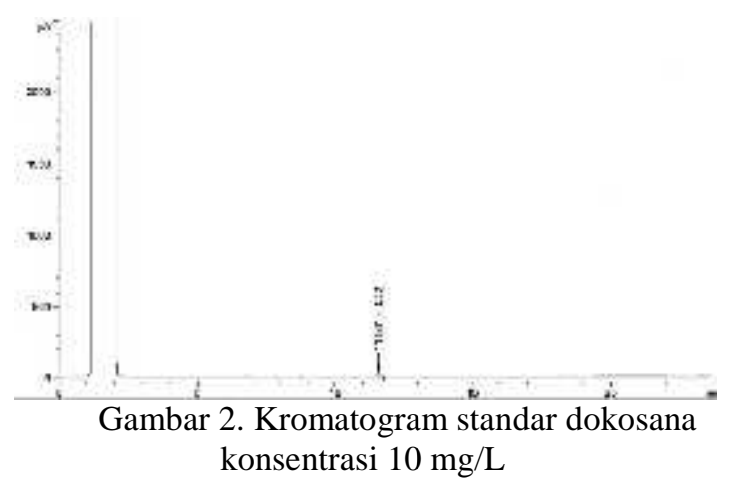

\subsection{Hasil Uji Presisi}

Uji presisi dilakukan untuk mengetahui kedekatan atau kesesuain antara hasil uji yang satu dengan yang lain dari sampel yang homogen pada serangkaian pengujian. Uji ini dapat digunakan untuk mengetahui adanya galat acak yang berasal dari ketidakstabilan arus listrik dan suhu kerja yang berbeda antara ruang preparasi dan ruang analisa yang tidak dapat dikendalikan. Uji presisi diukur sebagai persen simpangan baku relatif (\% RSD). Pengukuran yang dilakukan pada uji presisi ini hanya menetapkan keterulangan (repeatability) saja sebagai parameter presisi, yaitu dilakukan berulang kali oleh analis, kondisi, dan waktu yang sama. Uji presisi dilakukan dengan melakukan pengukuran sampel sebanyak 7 kali ulangan untuk menguji seberapa dekat hasil atau data yang didapat dari ulangan-ulangan tersebut. Pengukuran presisi pada penentuan petroleum hydrocarbonatom $\mathrm{C}_{22}$ (dokosana) dilakukan pada 2 konsentrasi, yaitu konsentrasi sedang (100 mg/L) dan konsentrasi tinggi (500 mg/L). Pengukuran presisi pada dua konsentrasi tersebut dimaksudkan untuk memastikan kebenaran data yang diperoleh. Hasil tersebut 
kemudian dievaluasi apakah menghasilkan data yang baik atau terdapat pengaruh dari perbedaan konsnetrasi tersebut. Hasil uji presisi dapat dilihat pada Tabel 2.

Tabel 2 Hasil uji presisi pada penetapan TPH

\begin{tabular}{|c|c|c|c|c|}
\hline \multirow{3}{*}{ Ulangan } & $\begin{array}{l}\text { Kudern } \\
\text { evapora }\end{array}$ & Danish & \multicolumn{2}{|c|}{ Rotary Evaporator } \\
\hline & \multicolumn{4}{|c|}{ Konsentrasi standar dokosana (mg/L) } \\
\hline & 100 & 500 & 100 & 500 \\
\hline 1 & 96.45 & 465.99 & 108.13 & 482.14 \\
\hline 2 & 101.01 & 475.45 & 110.45 & 497.32 \\
\hline 3 & 103.75 & 476.18 & 111.47 & 505.61 \\
\hline 4 & 104.17 & 478.61 & 112.32 & 506.74 \\
\hline 5 & 105.30 & 503.96 & 112.91 & 509.88 \\
\hline 6 & 106.45 & 508.55 & 113.82 & 520.81 \\
\hline 7 & 109.93 & 514.85 & 114.83 & 524.40 \\
\hline Rerata & 103.86 & 489.08 & 111.99 & 506.70 \\
\hline SD & 4.26 & 19.40 & 2.23 & 14.23 \\
\hline$\%$ RSD & 4.10 & 3.97 & 1.99 & 2.81 \\
\hline $2 / 3$ & 5.30 & 4.20 & 5.24 & 4.18 \\
\hline $\mathrm{CV}_{\text {Horwitz }}$ & & & & \\
\hline
\end{tabular}

Pengujian presisi pada penentuan dokosana dilakukan terhadap metode Kuderna Danish evaporator dan rotary evaporator untuk mengetahui perbandingan dua metode tersebut, sejauh mana kedua metode dapat memiliki keterulangan yang baik. Berdasarkan hasil percobaan uji presisi, \% RSD yang diperoleh pada pengujian dokosana dengan metode Kuderna Danishevaporator pada konsentrasi 100 dan $500 \mathrm{mg} / \mathrm{L}$ secara berturutturut sebesar 4.10 dan $3.97 \%$. Menurut AOAC (2005), bahwa nilai \% RSD < $5 \%$ memiliki ketelitian metode yang cukup teliti, sedangkan nilai $2 / 3 \mathrm{CV}_{\text {Horwitz }}$ yang terhitung sebesar 5.30 $\%$ pada konsentrasi $100 \mathrm{mg} / \mathrm{L}$ dan $4.20 \%$ pada konsentrasi $500 \mathrm{mg} / \mathrm{L}$. Nilai tersebut menunjukkan bahwa \% RSD dari hasil pengujian dengan metode Kuderna Danish evaporator lebih kecil dari $2 / 3 \quad \mathrm{CV}_{\text {Horwitz. }}$ Menurut Harmita [11], suatu metode pengujian dikatakan baik jika nilai \% RSD lebih kecil dari 2/3 $\mathrm{CV}_{\text {Horwitz, sehingga dapat dikatakan }}$ bahwa metode uji TPH dengan kromatografi gas mempunyai presisi yang baik. Hasil uji presisi dengan menggunakan metode rotary evaporator juga menghasilkan data yang baik, dengan nilai \% RSD pada konsentrasi 100 dan $500 \mathrm{mg} / \mathrm{L}$ sebesar 1.99 dan $2.81 \%$ dengan nilai $2 / 3 \mathrm{CV}_{\text {Horwitz }}$ sebesar 5.24 dan $4.18 \%$.
Berdasarkan hasil tersebut, dapat dikatakan bahwa pengujian TPH dengan metode rotary evaporator menghasilkan presisi yang lebih baik dibandingkan dengan Kuderna Danish evaporator. Hal ini dapat dilihat dari nilai \% RSD yang dihasilkan lebih kecil pada metode rotary evaporator, selain nilai \% RSD, presisi yang baik pada metode rotary evaporator diperoleh dari penggunaan alat yang telah terkalibrasi pada penambahan diklorometana.

\subsection{Hasil Uji Akurasi}

Uji akurasi dilakukan untuk mengetahui kedekatan antara hasil pengujian dengan nilai yang sebenarnya. Uji akurasi dilakukan dengan cara pengujian persen perolehan kembali (\% recovery). Perolehan kembali menunjukkan kemampuan suatu metode menghasilkan tingkat perolehan sejumlah konsentrasi analit yang ditambahkan dengan jumlah yang pasti dengan adanya pengaruh suatu analisis. Akurasi hasil analisis sangat tergantung kepada sebaran kesalahan sistematik di dalam keseluruhan tahapan analisis. Oleh karena itu, untuk mencapai akurasi yang tinggi hanya dapat dilakukan dengan cara mengurangi kesalahan sistematik. Nilai \% recovery yang mendekati $100 \%$ menunjukkan bahwa metode tersebut memiliki ketepatan yang baik dalam menunjukkan tingkat kesesuaian dari rata-rata suatu pengukuran yang sebanding dengan nilai sebenarnya. Hasil uji akurasi dapat dilihat pada Tabel 3 dan 4 .

Tabel 3. Hasil uji akurasi pada penetapan TPH pada konsentrasi $100 \mathrm{mg} / \mathrm{L}$

\begin{tabular}{ccccc}
\hline \multirow{2}{*}{ Ulangan } & $\begin{array}{c}\text { Kuderna Danish } \\
\text { evaporator }\end{array}$ & \multicolumn{2}{c}{$\begin{array}{c}\text { Rotary } \\
\text { evaporator }\end{array}$} \\
\cline { 2 - 5 } & $\begin{array}{c}\text { Konsentrasi } \\
\text { terukur } \\
(\mathrm{mg} / \mathrm{L})\end{array}$ & $\begin{array}{c}\text { Konsentrasi } \\
\text { Recovery }\end{array}$ & $\begin{array}{c}\text { Konk } \\
\text { terukur } \\
(\mathrm{mg} / \mathrm{L})\end{array}$ & Recovery \\
\hline 1 & 96.45 & 96 & 108.13 & 108 \\
2 & 101.01 & 101 & 110.45 & 110 \\
3 & 103.75 & 104 & 111.47 & 111 \\
4 & 104.17 & 104 & 112.32 & 112 \\
5 & 105.30 & 105 & 112.91 & 113 \\
6 & 106.45 & 106 & 113.82 & 114 \\
7 & 109.93 & 110 & 114.83 & 115 \\
\hline Rerata & 103.86 & 104 & 111.99 & 112 \\
\hline
\end{tabular}


Berdasarkan Tabel 3 dan 4 dapat dilihat bahwa kisaran nilai perolehan kembali yang didapatkan pada percobaan dengan metode Kuderna Danishevaporator sebesar 96-110\% dengan rerata sebesar $104 \%$. Nilai ini tidak berbeda jauh dengan nilai perolehan kembali dari metode rotary evaporator, yaitu sebesar 108-115\% dengan rerata sebesar $112 \%$, sedangkan kisaran perolehan kembali pada konsentrasi $500 \mathrm{mg} / \mathrm{L}$ dengan metode Kuderna Danish evaporator menunjukkan kisaran sebesar 93-103\% dengan rerata sebesar $97 \%$ dan pada metode rotary evaporator kisaran perolehan kembali yang didapat sebesar 96$105 \%$ dengan rerata sebesar $105 \%$.

\begin{tabular}{|c|c|c|c|c|}
\hline \multirow[b]{2}{*}{ Ulangan } & \multicolumn{2}{|c|}{$\begin{array}{c}\text { Kuderna } \\
\text { Danishevaporator }\end{array}$} & \multicolumn{2}{|c|}{ Rotary evaporator } \\
\hline & $\begin{array}{c}\text { Konsentrasi } \\
\text { terukur } \\
(\mathrm{mg} / \mathrm{L})\end{array}$ & $\begin{array}{c}\% \\
\text { Recovery }\end{array}$ & $\begin{array}{c}\text { Konsentrasi } \\
\text { terukur } \\
(\mathrm{mg} / \mathrm{L})\end{array}$ & $\begin{array}{c}\% \\
\text { Recovery }\end{array}$ \\
\hline 1 & 465.99 & 93 & 482.14 & 96 \\
\hline 2 & 475.45 & 95 & 497.32 & 99 \\
\hline 3 & 476.18 & 95 & 505.61 & 101 \\
\hline 4 & 478.61 & 96 & 506.74 & 101 \\
\hline 5 & 503.96 & 101 & 509.88 & 102 \\
\hline 6 & 508.55 & 102 & 520.81 & 104 \\
\hline 7 & 514.85 & 103 & 524.40 & 105 \\
\hline Rerata & 489.08 & 97 & 506.70 & 105 \\
\hline
\end{tabular}

Nilai perolehan kembali yang didapatkan dari kedua metode memenuhi persyaratan yang ditetapkan oleh AOAC [10] untuk kisaran perolehan kembali, yaitu 80-120\%. Hal ini menunjukkan bahwa kedua metode memiliki akurasi yang baik. Kesalahan negatif dan positif terjadi pada pengujian akurasi dengan kedua metode yang disebabkan oleh galat sistematik yang disebabkan oleh sifat mudah menguap diklorometana yang digunakan sebagai pelarut.

\subsection{Uji Beda Nyata}

Uji beda nyata dilakukan pada data yang telah didapatkan. Uji beda nyata dilakukan untuk mengetahui keberterimaan data hasil analisis dari dua metode yang berbeda. Pada percobaan, dilakukan uji beda nyata dengan cara membandingkan nilai TPH dari hasil pengukuran dengan metode Kuderna Danish evaporator dan rotary evaporator. Idealnya, kedua metode menghasilkan nilai TPH yang tidak berbeda nyata agar dapat saling menggantikan sebagai analisis rutin. Hasil pengukuran dari kedua metode dibandingkan secara statistika. Parameter yang dibandingkan adalah standar deviasi dan rerata melalui uji $\mathrm{F}$ dan uji $\mathrm{T}$ terhadap kedua metode. Perbandingan kedua metode tersebut dapat dilihat pada Tabel 5.

Tabel 5 Uji beda nyata metode Kuderna Danishevaporator dan rotary evaporator

\begin{tabular}{lll}
\hline $\begin{array}{l}\text { Konsentrasi } \\
(\mathrm{mg} / \mathrm{L})\end{array}$ & Parameter & Hasil \\
\hline & F-Hitung & 3.6493 \\
& Derajat bebas & 6 \\
& F-tabel $\{5 \% ;(6,6)\}$ & 5.820 \\
$100 \mathrm{mg} / \mathrm{L}$ & Hipotesis & $\mathrm{H}_{0}$ diterima \\
\cline { 2 - 3 } & T-hitung & 4.4734 \\
& Derajat bebas & 12 \\
& T-tabel & 2.18 \\
& Hipotesis & $\mathrm{H}_{0}$ ditolak \\
\hline & F-Hitung & 1.8586 \\
& Derajat bebas & 6 \\
& F-tabel $\{5 \% ;(6,6)\}$ & 5.820 \\
& Hipotesis & $\mathrm{H}_{0}$ diterima \\
\cline { 2 - 3 } $500 \mathrm{mg} / \mathrm{L}$ & T-hitung & 1.9376 \\
& Derajat bebas & 12 \\
& T-tabel & 2.18 \\
& Hipotesis & $\mathrm{H}_{0}$ diterima \\
\hline
\end{tabular}

Berdasarkan hasil yang diperoleh dari uji beda nyata yang dilakukan dapat diketahui bahwa varians dari kedua metode pada konsentrasi 100 dan $500 \mathrm{mg} / \mathrm{L}$ tidak berbeda nyata pada selang kepercayaan $95 \%$. Hal ini dapat diketahui melalui uji statistika yaitu uji Fischer (F). Nilai $F$ hitung yang diperoleh lebih kecil dibandingkan dengan $F$ tabel sehingga hipotesis nol $\left(\mathrm{H}_{0}\right)$ dari percobaan diterima. Uji $\mathrm{F}$ ini dapat menunjukkan adanya kesalahan acak yang terjadi. Kesalahan acak salah satunya disebabkan oleh ketidakkonsistenan perlakuan terhadap sampel. Kesalahan acak tidak dapat dihilangkan, namun dapat dikurangi dengan mengendalikan faktor yang dapat mempengaruhi hasil penetapan. 
Uji statistika lanjutan dari uji $\mathrm{F}$ adalah uji T. Uji ini dilakukan untuk mengetahui kedapatterimaan rerata dari data yang didapatkan oleh kedua metode. Setelah dilakukan uji $\mathrm{T}$, didapatkan bahwa nilai $\mathrm{T}$ hitung kedua metode pada konsentrasi 100 $\mathrm{mg} / \mathrm{L}$ lebih besar dari nilai $\mathrm{T}$ tabel, sehingga hipotesis nol tidak diterima, namun nilai $\mathrm{T}$ hitung pada konsentrasi $500 \mathrm{mg} / \mathrm{L}$ lebih kecil daripada $\mathrm{T}$ tabel. Hal ini menunjukkan bahwa hipotesis nol diterima, yaitu rerata kedua data tidak berbeda nyata pada selang kepercayaan $95 \%$. Hasil yang tidak berbeda nyata ini menandakan bahwa kedua metode dapat saling menggantikan sebagai analisis rutin pada konsentrasi di atas $100 \mathrm{mg} / \mathrm{L}$, sedangkan pada konsentrasi $100 \mathrm{mg} / \mathrm{L}$ sebaiknya digunakan metode kuderna danish evaporator yang menunjukkan akurasi yang lebih baik dari metode rotary evaporator. $\mathrm{Uji} \mathrm{T}$ dapat menunjukkan adanya galat sistematik yang terjadi pada pengukuran.

Ketidakberterimaannya $\mathrm{H}_{0}$ pada uji $\mathrm{T}$ dengan konsentrasi $100 \mathrm{mg} / \mathrm{L}$ dapat disebabkan oleh beberapa faktor, diantaranya adanya kesalahan sistematik dalam penentuan TPH dengan kedua metode. Selain itu, hasil pengukuran juga dapat disebabkan oleh konsentrasi. Semakin kecilnya konsentrasi sampel yang diukur, maka semakin mudah dipengaruhi oleh noise yang menyebabkan kurang stabilnya pengukuran sehingga persen kesalahan semakin tinggi. Faktor lain yang dapat menyebabkan ketidakberterimaannya $\mathrm{H}_{0}$ yaitu limit deteksi dan limit kuantitasi yang menunjukkan analit yang terkandung dalam sampel tidak terdeteksi pada konsentrasi 100 $\mathrm{mg} / \mathrm{L}$.

Metode Kuderna Danishevaporator dan rotary evaporator yang diujikan memiliki kelebihan dan kelemahan. Berdasarkan data yang diperoleh, presisi yang didapat dari metode rotary evaporator lebih baik dibandingkan dengan metode Kuderna Danish evaporator. Hal ini dapat dibuktikan dari segi keterulangan dan standar deviasi yang lebih baik daripada Kuderna Danish evaporator. Akan tetapi, dari segi akurasi metode Kuderna
Danishevaporator menunjukkan hasil yang lebih baik. Perolehan hasil akurasi yang lebih baik pada metode Kuderna Danish evaporator dikarenakan adanya kolom snyder yang berfungsi untuk menguapkan pelarut yang mudah menguap namun tetap mempertahankan analit yang akan dianalisis, selain itu terjadi proses pengembunan pada kolom snyder dimana fase gas dari analit berubah menjadi fase cair yang kemudian ditampung dalam collection tube sehingga perolehan kembali (recovery) yang didapat lebih baik [12].

Metode yang digunakan sebagai analisis rutin dalam penentuan TPH adalah metode rotary evaporator. Metode ini dipilih karena waktu yang dibutuhkan untuk analisis lebih efisien, yaitu 5 sampai 10 menit, sedangkan metode Kuderna Danish evaporator membutuhkan waktu 3 sampai 4 jam. Selain itu, dari segi teknis metode rotary evaporator lebih mudah dan aman dalam pengerjaannya.

\section{Kesimpulan}

Berdasarkan parameter uji verifikasi yang telah dilakukan terhadap metode Kuderna Danishevaporator dan rotary evaporator, diantaranya linearitas, presisi, dan akurasi menghasilkan data yang terpercaya dan memenuhi syarat keberterimaan. Uji beda nyata menunjukkan bahwa kedua metode tidak berbeda nyata pada konsentrasi $500 \mathrm{mg} / \mathrm{L}$, sehingga dapat disimpulkan bahwa metode Kuderna Danish dan rotary evaporator dalam penetapan kadar Total Petroleum Hydrocarbon secara kromatografi gas dapat saling menggantikan dan digunakan untuk analisis rutin.

\section{Saran}

Sebaiknya dilakukan pengujian limit deteksi dan limit kuantitasi pada kedua metode, sehingga dapat diketahui jumlah terkecil analit dalam sampel yang masih dapat dideteksi dan dikuantitasi secara tepat dalam penentuan TPH dengan kedua metode secara kromatografi gas. 


\section{Daftar Pustaka}

[1] A. Haris, Peranan Mikroba dalam Mendegradasi Minyak Bumi dan Fenol pada Air Terproduksi dari Industri perminyakan.Bogor : Institut Pertanian Bogor, 2003

[2] Charlena, A. Haris,Karwati, "Degradasi Hidrokarbon pada Tanah Tercemar Minyak Bumi dengan Isolat A10 dan D8", Seminar Nasional Sains II,2009, pp. 124-136

[3] J. Li, J. Zhang, Y. Lu, Y. Chen, S. Dong, andH. Shim, "Determination of total petroleum hydrocarbons (TPH) in agricultural soils near a petrochemical complex in Guangzhou", Environ. Monit. Assess. vol. 184, pp.281-287, 2012.

[4] G. Schwartz, E. Ben-dor, and G. Eshel, "Quantitative Analysis of Total Petroleum Hydrocarbons in Soils: Comparison between Reflectance Spectroscopy and Solvent Extraction by 3 Certified Laboratories", Applied and Environmental Soil Science, vol. 2012, pp. 1-10, 2012.

[5] T. Rauckyte, S. ak, Z. Pawlak, and A. Oloyede, "Determination of Oil and Grease, Total Petroleum Hydrocarbons and Volatile Aromatic Compounds in Soil and Sediment Samples",J. Envir. Eng. and Landscape Management, vol. 18, no. 3, pp. 163-169, 2010.

[6] A. O. Adeniji, O. O. Okoh, andA. I. Okoh, "Analytical Methods for the Determination of the Distribution of Total Petroleum Hydrocarbons in the Water and Sediment of Aquatic Systems: A Review",J. Chemistry, vol. 2017, pp. 1-13, 2017.

[7] P. Paíga, L. Mendes, J. T. Albergaria, andC. M. Delerue-matos, "Determination of total petroleum hydrocarbons in soil from different locations using infrared spectrophotometryand gas chromatography", Chemical Papers,vol. 66 no. 8, pp. 711-721,2012.

[8] K. Grob,Split and Splitless Injection for Quantitative Gas Chromatography, Fourth Edition. Weinheim : WILEY-VCH, 2001.

[9] C. F. Poole, The Essence of Chromatography. Amsterdam : Elsevier Science, 2003.
[10] AOAC, Official Method of Analysis of AOAC International. Ed.18. Maryland: AOAC International, 2005.

[11] Harmita, "Petunjuk pelaksanaan validasi metode dan cara perhitungannya".Majalah Ilmu Kefarmasian.vol. 1, no. 3, pp. 117135, 2004.

[12] J. G. Speight, The Chemistry and Technology of Petroleum, Fourth Edition. New York : Taylor and Francis Group, 2006. 